\section{Storage Temperature and Fruit Calcium Alter the Sequence of Ripening Events of 'd'Anjou' Pears}

\author{
D. Gerasopoulos \\ Department of Horticulture, Mediterranean Agronomic Institute of Chania, \\ Odos Makedonias, Chania, 73100-Greece

\section{D.G. Richardson} \\ Department of Horticulture, Oregon State University, Corvallis OR 97331-7304
}

Additional index words. Pyrus communis, postharvest physiology, ethylene synthesis, firmness, ripening

\begin{abstract}
Pear trees (Pyrus communis L.), cv. d'Anjou, received foliar applications of X-77 surfactant and $32.3 \mathrm{mM} \mathrm{CaCl}_{2}$ at 55, 85, 125, and 137 days after full bloom (DAFB) and fruit were harvested at 147 DAFB. Samples of fruit were stored in air either at $20{ }^{\circ} \mathrm{C}$ continuously or at 5 or $10{ }^{\circ} \mathrm{C}$ for several periods, then transferred to $20^{\circ} \mathrm{C}$, to determine the effects of storage temperature and $\mathrm{CaCl}_{2}$ treatments on the development of the ethylene climacteric and flesh firmness loss. Control fruits held continuously at $20{ }^{\circ} \mathrm{C}$ required 70 days for the onset of climacteric ethylene production, which commenced when firmness had decreased to $\approx 20 \mathrm{~N}$. Calcium-sprayed fruit required 80 days at $20{ }^{\circ} \mathrm{C}$ before the rise in ethylene and resisted softening for $\approx 50$ days. Regardless of calcium treatment, pears stored at 5 or $10{ }^{\circ} \mathrm{C}$ required only 40 days to produce climacteric ethylene; fruit softening and internal ethylene concentration after storage at $10{ }^{\circ} \mathrm{C}$ were intermediate between those of fruits stored at 5 and $20^{\circ} \mathrm{C}$. Calcium application did not alter the sequence of ripening events.
\end{abstract}

Fruit of 'd'Anjou', a winter pear variety, require $\approx 60 \mathrm{~d}$ at $-1{ }^{\circ} \mathrm{C}$ to gain the ability to produce ethylene and ripen upon transfer to room temperature (Chen et al., 1982). The duration of chilling temperatures required to induce ripening and the sequence of ripening events vary, however, depending on storage temperature and fruit calcium concentration, and the pears lose firmness more rapidly as storage temperature increases. At high temperatures $\left(5\right.$ to $\left.20^{\circ} \mathrm{C}\right)$, firmness loss can take place before the climacteric rise in $\mathrm{CO}_{2}$ (Porritt, 1964) or ethylene (Gerasopoulos and Richardson, 1997d). Thus, 'd'Anjou' pears stored at $20^{\circ} \mathrm{C}$ reach complete ripening capacity within 50 to 60 d (Gerasopoulos and Richardson, 1997d). Calcium is applied to prevent physiological disorders and delay ripening in avocado (Tingwa and Young, 1974), apples, pears (Richardson and Lombard, 1979), small fruit (Ali et al., 1994), and kiwifruit (Gerasopoulos et al., 1994). When 'd'Anjou' pears were treated with $\mathrm{Ca}$, they required longer storage at $-1{ }^{\circ} \mathrm{C}$ in order to initiate autocatalytic ethylene production and ripening than did control fruit (Richardson and Lombard, 1979; Vaz, 1984). Although winter pears require chilling to ripen normally, treating immature or mature 'd'Anjou' pears with ethylene can induce softening and ripening (Wang et al., 1972).

Received for publication 28 Oct. 1987. Accepted for publication 13 Aug. 1998. The cost of publishing this paper was defrayed in part by the payment of page charges. Under postal regulations, this paper therefore must be hereby marked advertisement solely to indicate this fact.
The purpose of this study was to determine the effects of storage temperature and preharvest calcium application on the ripening capability of 'd'Anjou' pear, as measured by climacteric ethylene production and firmness loss.

\section{Materials and Methods}

General procedures. Two groups of 10 mature 'd'Anjou' pear trees at the MidColumbia Experiment Station, Hood River, Ore., were sprayed with $32.3 \mathrm{~mm} \mathrm{CaCl}_{2}$ plus X-77 surfactant or surfactant only (control) $55,85,125$, and 137 DAFB. The fruit were harvested at 147 DAFB and placed directly into perforated polyethylene bag liners (folded over $)$ in cartons $(30 \times 50 \times 30 \mathrm{~cm})$ holding $\approx 20$ $\mathrm{kg}$ of fruit each, and stored in air at 5 or $10^{\circ} \mathrm{C}$. Additional fruit were placed in $20-\mathrm{L}$ jars and stored at $20^{\circ} \mathrm{C}$ for the measurement of internal fruit ethylene and flesh firmness. Fruits were not treated with fungicide after harvest to allow evaluation of possible effects on storage rots; however, they were screened for cork spotincidence throughout the experiment. Only sound fruit were used. Fruits were stored at 5 or $10^{\circ} \mathrm{C}$ for 25,40 , and $55 \mathrm{~d}$ and then placed in $20-\mathrm{L}$ jars at $20^{\circ} \mathrm{C}$ to ripen for $11 \mathrm{~d}$ for the measurement of internal fruit ethylene and flesh firmness. All jars were ventilated with humidified air at $1 \mathrm{~L} \cdot \mathrm{min}^{-1} ; \mathrm{CO}_{2}$ accumulation (as monitored by infrared analysis) did not exceed $0.5 \%$.

Ripening characteristic determinations. Five fruit per treatment were taken from the 20-L jars every other day and the internal ethylene concentration (IEC) was measured by extracting a $1-\mathrm{mL}$ sample from waterimmersed fruit. Ethylene was determined with a flame ionization gas chromatograph (Carle Model 311; Carle instruments, Fullerton, Calif.) equipped with a 2-m-long $\times 3$-mm-diameter column packed with $80 / 100$ mesh activated alumina. While threshold ethylene may be in the range of 0.05 to $0.5 \mu \mathrm{L} \cdot \mathrm{L}^{-1}$ (Wang et al., 1972), for comparative purposes an internal ethylene concentration of $1 \mu \mathrm{L} \cdot \mathrm{L}^{-1}$ was chosen as being above the concentration having threshold physiological activity (Gerasopoulos and Richardson, 1996). Flesh firmness was measured on the same five fruits with a force gauge (Hunter model LKG-1; Western Industrial Supply, San Jose, Calif.) equipped with an 8-mm tip in a Univ. of CaliforniaDavis penetrometer, using two pared surfaces on opposite sides of the fruit at the equator.

Calcium determinations. At the termination of each ripening experiment, all five fruit groups were washed and calcium was extracted by the method of Perring (1968), as modified by Richardson and Al-Ani (1982). Ten grams of a 1 fruit : 1 water homogenate were transferred into a serum-test tube $; 10 \mathrm{~mL}$ of concentrated $\mathrm{HCl}$ (37.8\% A.R.) was added and the tube was capped. The suspension was boiled for $20 \mathrm{~min}$ in a water bath, cooled, then filtered through Whatman 41 low-ash paper. Strontium chloride was added to all extracts to a final concentration of $3 \%$ to reduce atomic absorption mineral interference. The filtrate was diluted to $25 \mathrm{~mL}$ with distilled water, and calcium was determined with an atomic absorption spectrophotometer (Perkin Elmer Model 303; Perkin Elmer, San Jose, Calif.) calibrated against $\mathrm{CaCl}_{2}$ standards in acid.

Statistical analysis. For comparisons between treatments during poststorage ripening, LSDS were calculated with the SAS (SAS Institute, Cary, N.C.) statistical computer software. For comparing firmness and internal ethylene, LSDS were obtained by application of factorial analysis.

\section{Results and Discussion}

The average fruit calcium concentrations (fresh fruit basis) were 56 and $66 \mu \mathrm{g} \cdot \mathrm{g}^{-1}$ in the controls and the calcium-treated pears, respectively $\left(\mathrm{LSD}_{0.05}=9.2\right)$. At harvest IEC was $0.16 \mu \mathrm{L} \cdot \mathrm{L}^{-1}$ for the control fruit and $0.08 \mu \mathrm{L} \cdot \mathrm{L}^{-1}$ in calcium-sprayed pears $\left(\mathrm{LSD}_{0.05}=0.12\right)$. Flesh firmness was 67.3 and $71.7 \mathrm{~N}\left(\mathrm{LSD}_{0.05}=6.2\right)$ for control and calcium treated-pears, respectively. Preharvest $\mathrm{CaCl}_{2}$ sprays have been reported to increase 'd' Anjou' pear Ca by about $10 \mu \mathrm{g} \cdot \mathrm{g}^{-1}$ and to improve firmness retention at harvest by about $5 \mathrm{~N}$ (Gerasopoulos and Richardson, 1996; Richardson and Lombard, 1979).

Storage of 'd' Anjou' pears at $-1^{\circ} \mathrm{C}$ maintains firmness at about harvest levels (maximum loss of 5\%) while stimulating ACC oxidase activity, leading to accumulation of ACC (Blankenship and Richardson, 1985; Gerasopoulos and Richardson, 1997d) and increasing mRNA expression of genes complementary to clones associated with ethylene biosynthetic enzymes (Cregoe et al., 1993). Thereafter, 
changes at the transcriptional level (Wilson et al., 1990), or in protein population (Cregoe et al., 1993), occur as fruits are placed at ripening temperatures.

Firmness of pears decreased to $50 \mathrm{~N}$ when held at $5{ }^{\circ} \mathrm{C}$ for $25 \mathrm{~d}$, then transferred at $20^{\circ} \mathrm{C}$ for $11 \mathrm{~d}$ while IEC remained $<0.6 \mu \mathrm{L} \cdot \mathrm{L}^{-1}$ (Fig. 1A). However, considerable loss in firmness and an increase in IEC occurred when pears were held at $20^{\circ} \mathrm{C}$ after being held for $40 \mathrm{~d}$ at $5^{\circ} \mathrm{C}$. The pears lost most of their firmness and contained $>10 \mu \mathrm{L} \cdot \mathrm{L}^{-1}$ ethylene during storage at $5{ }^{\circ} \mathrm{C}$ for $>40 \mathrm{~d}$. Firmness loss and IEC further increased during poststorage holding at $20{ }^{\circ} \mathrm{C}$ (Fig. 1A). Chen et al. (1982) and Sfakiotakis and Dilley (1974) reported similar response to temperature in mature 'Bosc' pears stored at $5{ }^{\circ} \mathrm{C}$, which required less time to ripen than did fruit stored at lower or higher temperatures.

Fifty percent firmness loss was evident in pears held at $20^{\circ} \mathrm{C}$ following $25 \mathrm{~d}$ at $10^{\circ} \mathrm{C}$, while IEC during this period remained between 0.03 and $0.6 \mu \mathrm{L} \cdot \mathrm{L}^{-1}$ (Fig. 1B). The early loss in firmness with little change in ethylene production was similar to the response of pears held continuously at $20^{\circ} \mathrm{C}$ for $40 \mathrm{~d}$ (Fig. 2). Pears stored at $10{ }^{\circ} \mathrm{C}$ for $40 \mathrm{~d}$ or more ripened following a sequence of events similar to those occurring in pears held at $5{ }^{\circ} \mathrm{C}$, in which firmness started to decrease during storage prior to significant accumulation of ethylene. Firmness continued to decrease while IEC peaked at $\approx 55 \mu \mathrm{L} \cdot \mathrm{L}^{-1}$, following transfer from 5 to $20^{\circ} \mathrm{C}$ (Fig. 1B).

Firmness during the first $20 \mathrm{~d}$ of storage at $20^{\circ} \mathrm{C}$ changed little, then decreased to $15 \mathrm{~N}$ on day 70 , while the IEC showed a climacteric rise after $55 \mathrm{~d}$ and peaked at $65 \mu \mathrm{L} \cdot \mathrm{L}^{-1}$ after 70 d (Fig. 2). Storage of 'd' Anjou' pears at $20^{\circ} \mathrm{C}$ without a chilling treatment does not prevent firmness loss, nor does it prevent development of the capacity for the climacteric rise in $\mathrm{CO}_{2}$ (Porrit, 1960) or ethylene (Gerasopoulos and Richardson, 1997d). However, the sequence of ripening events following storage at $20^{\circ} \mathrm{C}$ differs from that after $-1{ }^{\circ} \mathrm{C}$ storage. In fruit stored at $20^{\circ} \mathrm{C}$, the rise in IEC occurs well after firmness loss has commenced (Fig. 2), whereas for fruit stored at $-1{ }^{\circ} \mathrm{C}$ the rise in IEC occurs at the same time that firmness loss begins (Gerasopoulos and Richardson, 1997c). When pears reach firmness of $30 \mathrm{~N}$ during $20{ }^{\circ} \mathrm{C}$ storage, sensitivity of the fruit to exogenous propylene is greatest (Gerasopoulos and Richardson, 1997a) and the chilling requirement is least (Gerasopoulos and Richardson, 1997b).

Calcium-treated pears start softening when the IEC exhibits a climacteric rise after $70 \mathrm{~d}$ of storage at $-1{ }^{\circ} \mathrm{C}$; this occurs $\approx 15 \mathrm{~d}$ later than in fruit not treated with calcium (Gerasopoulos and Richardson, 1997c). The effect of calcium in delaying ethylene production may be related to the decrease in the activity of ACC oxidase that occurs in apples (Guan et al., 1991). Even though calcium treatment extended the time required at $-1{ }^{\circ} \mathrm{C}$ to permit ethylene production upon transfer at $20^{\circ} \mathrm{C}$, it did not alter the sequence of events in ripening 'd'Anjou' pears following $-1^{\circ} \mathrm{C}$ storage (Gerasopoulos and Richardson, 1997c).

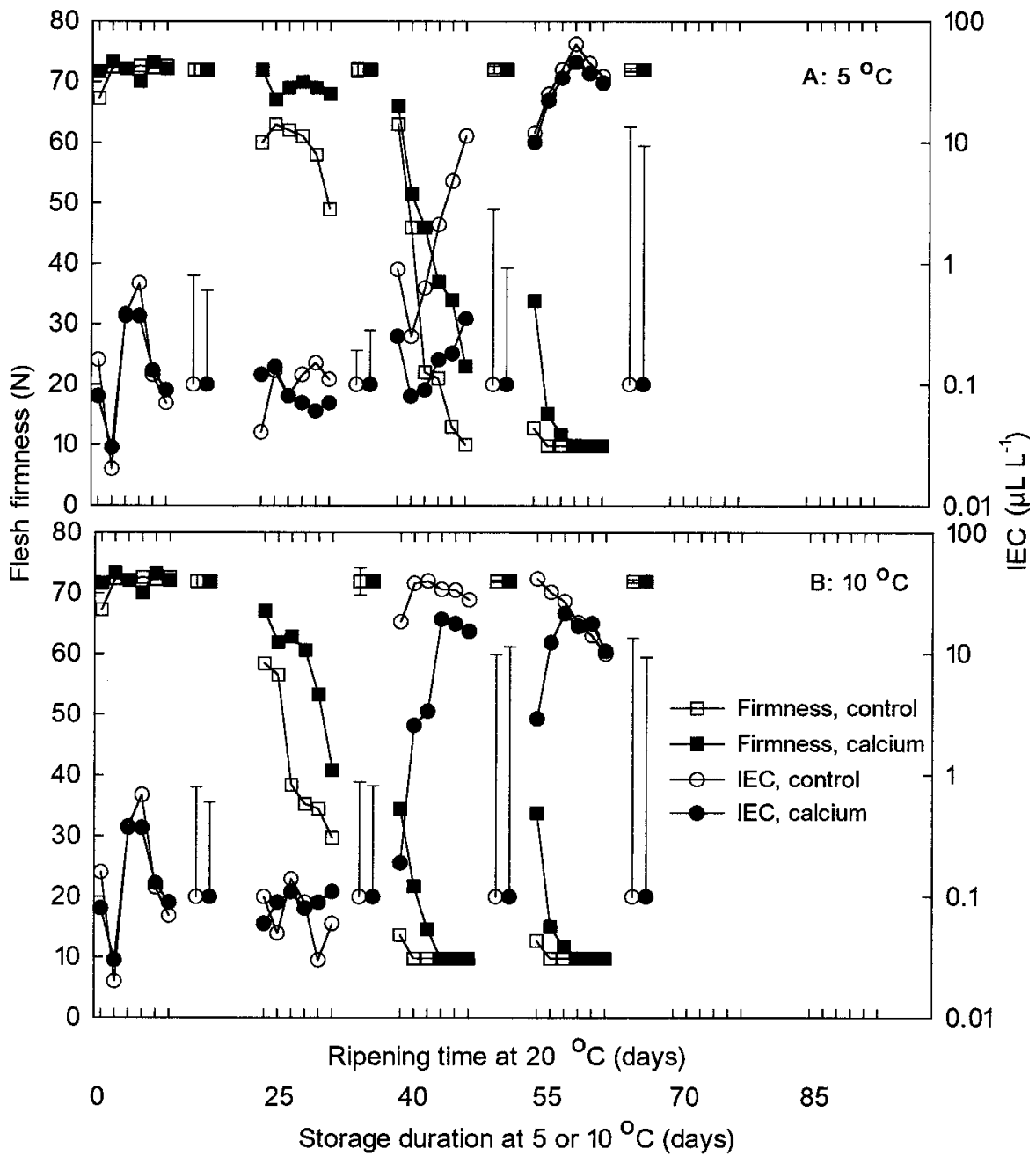

Fig. 1. Flesh firmness and internal ethylene concentration (IEC) of 'd' Anjou' pears sprayed with water (open symbols) or $32.3 \mathrm{mM} \mathrm{CaCl}_{2}$ (closed symbols) during fruit development, then stored at $5(\mathbf{A})$ or $10^{\circ} \mathrm{C}(\mathbf{B})$ for 25,40 , or $55 \mathrm{~d}$, followed by ripening at $20^{\circ} \mathrm{C}$ for $11 \mathrm{~d}$. Vertical bars at the end of each ripening series represent LSDS at $P \leq 0.05$. Data for each storage duration were recorded at $1,3,5,7,9$, and $11 \mathrm{~d}$ after transfer from 5 or 10 to $20^{\circ} \mathrm{C}$.

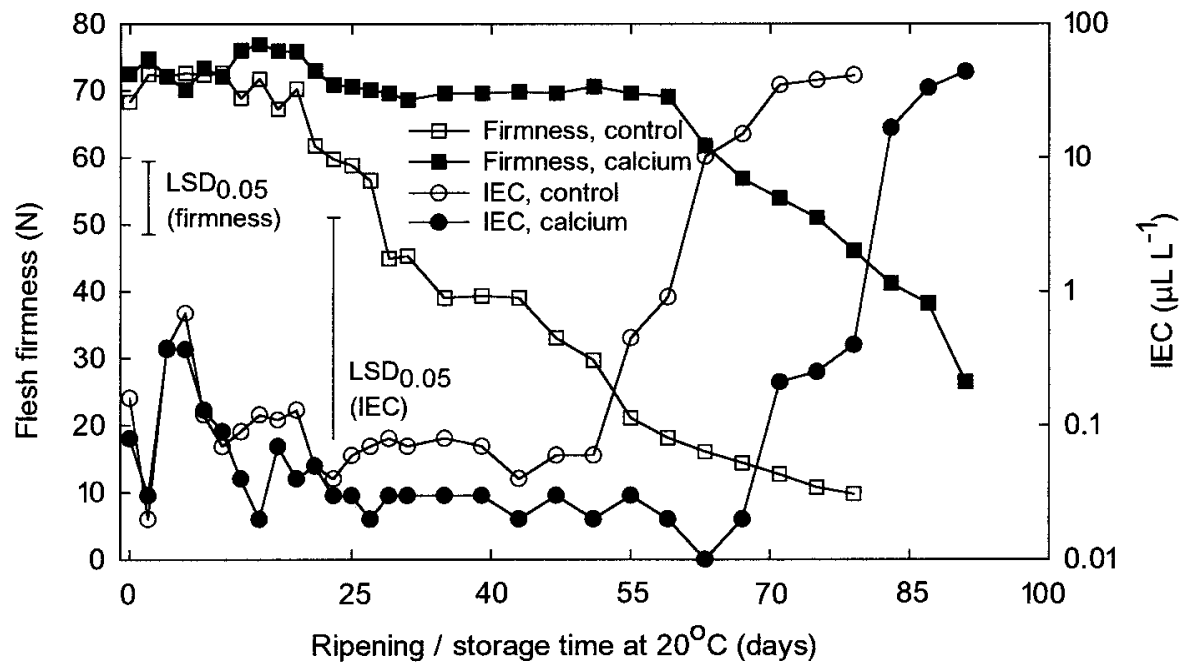

Fig. 2. Flesh firmness and internal ethylene concentration (IEC) of 'd'Anjou' pears sprayed with water (open symbols) or $32.3 \mathrm{~mm} \mathrm{CaCl}_{2}$ (closed symbols) during fruit development, then held continuously at $20^{\circ} \mathrm{C}$. 
Calcium-treated and control pears stored at 5 or $10{ }^{\circ} \mathrm{C}$ ripened simultaneously. The time required to induce ethylene production was 40 $\mathrm{d}, 30 \mathrm{~d}$ less than that reported for fruit stored at $-1^{\circ} \mathrm{C}$ (Gerasopoulos and Richardson, 1997c). Calcium did not alter the sequence of changes in firmness and IEC following poststorage holding at $20^{\circ} \mathrm{C}$, but delayed the development of ripening (Fig. $1 \mathrm{~A}$ and $\mathrm{B}$ ). Calcium-treated fruit were firmer than the control fruit at harvest and during storage at 5 or $10^{\circ} \mathrm{C}$ (Fig. $1 \mathrm{~A}$ and $\mathrm{B}$ ); those held continuously at $20{ }^{\circ} \mathrm{C}$ retained most of their initial firmness through $55 \mathrm{~d}$, whereas the firmness of the controls decreased after $20 \mathrm{~d}$. Calcium-treated fruits softened to $25 \mathrm{~N}$ after $90 \mathrm{~d}$ of storage at $20^{\circ} \mathrm{C}$ (Fig. 2). Their IEC was $\approx 0.1 \mu \mathrm{L} \cdot \mathrm{L}^{-1}$ from harvest through $68 \mathrm{~d}$ and exhibited a climacteric rise at $80 \mathrm{~d}$. This was $15 \mathrm{~d}$ later than for the control pears (Fig. 2). However, increased fruit calcium did not alter the sequence of ripening during storage at $20^{\circ} \mathrm{C}$, as was shown for fruit stored at $-1{ }^{\circ} \mathrm{C}$ (Gerasopoulos and Richardson, 1997d).

Major effects of calcium application on firmness $(+4$ to $+30 \mathrm{~N})$ were observed only in fruits stored at $20^{\circ} \mathrm{C}$ (Fig. 2). During storage at 5 or $10^{\circ} \mathrm{C}$, calcium-treated fruits exhibited delayed or reduced ethylene production relative to the controls (Fig. $1 \mathrm{~A}$ and B). Calciumtreatment of pears stored at $20^{\circ} \mathrm{C}$ markedly delayed production of climacteric ethylene (Fig. 2). These data are consistent with those of other studies in which calcium treatments increased firmness in pears and other fruit (Ali et al., 1994; Gerasopoulos et al., 1994; Vaz, 1984). The greater firmness of calciumtreated fruit may result from calcium interacting directly with cell wall pectic substances, resulting in cell wall stiffening. Calcium may also act by reducing the activity of cell walldegrading enzymes. Endo-polygalacturonase is the enzyme suggested to be primarily responsible for softening in 'Conference' (Bartley et al., 1982) and 'Bartlett' (Ahmed and Labavich, 1980) pear tissues during ripening. Polygalacturonase activity is reduced by addition of Ca to the substrate (Corden, 1965). This may explain the delayed and slower softening of Ca-treated fruit in the present study (Fig. $1 \mathrm{~A}$ and $\mathrm{B}$ ).

The ripening resistance mechanism of ' $d$ 'Anjou' pears is strongly counteracted (within $10 \mathrm{~d}$ ) by treatment with exogenous ethylene (Wang et al., 1972) or propylene (Gerasopoulos and Richardson, 1996), and is moderately counteracted by low storage temperature (within 40-60 d). Calcium also inhibits ripening, but treatment with propylene $(>1$ $\left.\mu \mathrm{L} \cdot \mathrm{L}^{-1}\right)$ or storage at temperatures that stimulate ripening $\left(\approx 10^{\circ} \mathrm{C}\right)$ lessens the effect of calcium. The effects of calcium are maxi- mized at nonchilling temperatures $\left(20^{\circ} \mathrm{C}\right)$ or at ripening-inhibiting temperatures of about $1{ }^{\circ} \mathrm{C}$.

The normal sequence of ripening events for pears, following induction of their capacity to produce ethylene by storage at chilling temperatures (Knee et al., 1983; Sfakiotakis and Dilley, 1973; Wilson et al., 1990), is characterized by firmness loss paralleling the climacteric rise in IEC. This sequence does not occur when 'd' Anjou' pears are exposed to nonchilling temperatures; firmness loss precedes the climacteric increase in IEC. Storage of 'd'Anjou' pears at chilling temperatures stimulates ethylene biosynthesis (Gerasopoulos and Richardson 1997d), and the increase in sensitivity to exogenous propylene is proportional to storage time (Gerasopoulos and Richardson 1997a). Storage at nonchilling temperatures stimulates ethylene biosynthesis only after firmness declines to $30 \mathrm{~N}$ (Gerasopoulos and Richardson 1997a, 1997b).

Based on these observations, we suggest that temperatures between -1 and $20^{\circ} \mathrm{C}$ stimulate both ripening phenomena (firmness loss and increase in IEC), thus resulting in faster ripening in addition to minimizing the effects of calcium.

\section{Literature Cited}

Ahmed, E.A. and J.M. Labavitch. 1980. Cell wall metabolism in ripening fruit. I. Cell wall changes in ripening 'Bartlett' pears. Plant Physiol. 65:1009-1013.

Ali, G., G. Stavroulakis, and D. Gerasopoulos. 1994. The effect of pre-harvest $\mathrm{CaCl}_{2}$ treatments on the quality of raspberries during harvest and storage at $0{ }^{\circ} \mathrm{C}$, p. $65-69$. In: A. Ait-Oubahou and M. El Otmani (eds.). Postharvest physiology, pathology and technologies for horticultural commodities: Recent advances. Inst. Agron. \& Veterinaire Hassan II, Agadir, Morocco.

Bartley, I.M., M. Knee, and M.A. Casimir. 1982. Fruit softening I. Changes in cell wall composition and endo-polygalacturonase in ripening pears. J. Expt. Bot. 137:1248-1255.

Blankenship, S.M. and D.G. Richardson. 1985. Development of ethylene induced ripening in 'd'Anjou' pears during the cold requirement for ripening. J. Amer. Soc. Hort. Sci. 110:520523.

Chen, P.M., D.G. Richardson, and W.M. Mellenthin. 1982. Differences in biochemical composition between 'Beurre d'Anjou' and 'Bosc' pears during fruit development and storage. J. Amer. Soc. Hort. Sci. 107:807-812.

Corden, M.E. 1965. Influence of calcium nutrition on fusarium wilt of tomato and polygalacturonase activity. Phytopathology 55:222-224.

Cregoe, B.A., G.S. Ross, and C.B. Watkins. 1993. Changes in protein and mRNA expression during cold storage of 'Cox's Orange Pippin' apple fruit. Acta Hort. 326:315-25.

Gerasopoulos, D., V. Chouliaras, and S. Lionakis.
1994. Effects of preharvest calcium sprays on maturity and storability of 'Hayward' kiwifruit. Postharvest Biol. Technol. 7:65-72.

Gerasopoulos, D. and D.G. Richardson. 1996. Effects of exogenous propylene and fruit calcium on ripening of non-chilled and chilled 'd' Anjou' pears. Postharvest Biol. Technol. 8:111-120.

Gerasopoulos, D. and D.G. Richardson. 1997a. Differential propylene induced ethylene production in 'd'Anjou' pears during storage at chilling and non-chilling temperatures. J. Hort. Sci. 72:571-575.

Gerasopoulos, D. and D.G. Richardson. 1997b. Effects of storage at chilling and non-chilling temperatures on ripening and chilling requirements of 'd'Anjou' pears. HortScience 32:10921094.

Gerasopoulos, D. and D.G. Richardson. 1997c. Fruit maturity and calcium affect chilling requirement and ripening of 'd'Anjou' pears. HortScience 32:911-913.

Gerasopoulos, D. and D.G. Richardson. 1997d. Time separation of cell wall softening and chlorophyll loss from the autocatalytic ethylene pathway and other ripening events of ' $\mathrm{d}$ 'Anjou' pears when held at $20^{\circ} \mathrm{C}$ compared to $-1{ }^{\circ} \mathrm{C}$. J. Amer. Soc. Hort. Sci. 122: 680-685.

Guan, J.F., H.R. Shu, and T.D. Huang. 1991. The effect of calcium on ethylene production in 'Starkrimson' apple. Acta Hort. Sinica 18:205209.

Knee, M., N.E. Looney, S.G.S. Hatfield, and S.M. Smith. 1983. Initiation of rapid ethylene synthesis by apple and pear fruits in relation to storage temperature. J. Expt. Bot. 34:1207-1212.

Perring, M.A. 1968. Mineral composition of apples, VII. Further investigations into the relationship between composition and disorders of the fruit. J. Sci. Food Agr. 19:640-645.

Porritt, S.W. 1964. The effect of temperature on post-harvest physiology and storage life of pears. Can. J. Plant Sci. 44:568-579.

Richardson, D.G. and A.M. Al-Ani. 1982. Ca and nitrogen effects on 'd'Anjou' pear fruit respiration and ethylene evolution. Acta Hort. 124:195201.

Richardson, D.G. and P.B. Lombard 1979. Cork spot of 'd'Anjou' pear: Control by calcium sprays. Commun. Soil Sci. Plant Anal. 10:383-389.

Sfakiotakis, E.M. and D.R. Dilley. 1974. Induction of ethylene production in 'Bosc' pears by preharvest cold stress. HortScience 9:336-338.

Tingwa, P.O. and R.E. Young. 1974. The effect of calcium on the ripening of avocado (Persea americana Mill.) fruits. J. Amer. Soc. Hort. Sci. 99:540-542.

Vaz, R.L. and D.G. Richardson. 1985. Effect of calcium on respiration rate, ethylene production and occurrence of cork spot in 'd'Anjou' pears (Pyrus communis L.). Acta Hort. 157:227-236.

Wang, C.Y., W.M. Mellenthin, and E. Hansen. 1972. Maturation of 'd'Anjou' pears in relation to chemical composition and reaction to ethylene. J. Amer. Soc. Hort. Sci. 97:9-12.

Wilson, I.D., G.A. Tucker, M. Knee, and D. Grierson. 1990. Changes in mRNA during low temperature storage and ripening of pears. Phytochemistry 29:2407-2409. 